\title{
AUTORADIOGRAPHIC LOCALIZATION OF ADENOSINE RECEPTORS IN RAT BRAIN USING [ $\left.{ }^{3} \mathrm{H}\right]$ CYCLOHEXYLADENOSINE ${ }^{1}$
}

\author{
ROBERT R. GOODMAN AND SOLOMON H. SNYDER ${ }^{2}$ \\ Departments of Neuroscience, Pharmacology and Experimental Therapeutics, Psychiatry and Behavioral Sciences, The \\ Johns Hopkins University School of Medicine, Baltimore, Maryland 21205
}

Received January 19, 1982; Revised March 23, 1982; Accepted April 7, 1982

\begin{abstract}
Adenosine $\left(\mathrm{A}_{1}\right)$ receptor binding sites have been localized in rat brain by an in vitro light microscopic autoradiographic method. 'The binding of $\left[{ }^{3} \mathrm{H}\right] N^{6}$-cyclohexyladenosine to slide-mounted rat brain tissue sections has the characteristics of $\mathrm{A}_{1}$ receptors. It is saturable with high affinity and has appropriate pharmacology and stereospecificity. The highest densities of adenosine receptors occur in the molecular layer of the cerebellum, the molecular and polymorphic layers of the hippocampus and dentate gyrus, the medial geniculate body, certain thalamic nuclei, and the lateral septum. High densities also are observed in certain layers of the cerebral cortex, the piriform cortex, the caudate-putamen, the nucleus accumbens, and the granule cell layer of the cerebellum. Most white matter areas, as well as certain gray matter areas, such as the hypothalamus, have negligible receptor concentrations. These localizations suggest possible central nervous system sites of action of adenosine.
\end{abstract}

A variety of evidence suggests that adenosine has a neuromodulatory role in the brain. Adenosine inhibits neuronal firing in most situations (Phillis and Wu, 1981) and alters adenylate cyclase activity via at least two distinct membrane-associated receptors (van Calker et al., 1979). Adenosine $A_{1}$ receptors display nanomolar affinities for adenosine and stereospecificity for phenylisopropyladenosine (PIA) isomers and are associated with a reduction of adenylate cyclase activity. $\mathrm{A}_{2}$ receptors have micromolar affinity for adenosine and little stereoselectivity for PIA isomers and mediate adenylate cyclase enhancement (Londos and Wolff, 1977; van Calker et al., 1979; Smellie et al., 1979). Methylxanthines are the best characterized antagonists of adenosine receptors, blocking both the elevations and depressions of adenylate cyclase, hence influencing both $A_{1}$ and $A_{2}$ receptors with similar potencies (Daly et al., 1981). The behavioral stimulant effects of xanthines may be associated with the blockade of adenosine receptors (Phillis

\footnotetext{
' This work was supported by United States Public Health Service Grants DA-00266, MH-18501, and NS-16375, Research Scientist Award DA-00074 to S. H. S., Training Grant GM-07309 to R. R. G., and grants from the McKnight Foundation and International Life Sciences Institute. We would like to acknowledge the expert technical and photographic assistance of Lynda Hester, Roberta Proctor, and Naomi Taylor and the superb manuscript preparation of Nancy Bruce and Dawn Hanks.

${ }^{2}$ To whom correspondence should be addressed at Department of Neuroscience, Johns Hopkins University School of Medicine, 725 North vivolfe Street, Baltimore, MD 21205.
}

and $\mathrm{Wu}, 1981)$ based on the close correlation between their central stimulant potencies and affinities for adenosine receptor binding sites (Snyder et al., 1981; Daly et al., 1981). It has been difficult to determine whether adenosine, like other neurotransmitter candidates, is localized to specific neuronal systems since histochemical means of localizing adenosine-containing neuronal elements have not been developed.

An alternative means of localizing the sites of synaptic action of putative neurotransmitters is to visualize their receptors at a microscopic level by autoradiography using the elegant techniques developed by Young and Kuhar (1979b). It has been possible to label adenosine receptors with agonists such as $\left[{ }^{3} \mathrm{H}\right] N^{6}$-cyclohexyladenosine $\left(\left[{ }^{3} \mathrm{H}\right]\right.$ CHA; Bruns et al., 1980), [ $\left.{ }^{3} \mathrm{H}\right] 2$-chloroadenosine (Williams and Risley, 1980), and $\left[{ }^{3} \mathrm{H}\right]$ phenylisopropyladenosine ( $\left[{ }^{3} \mathrm{H}\right] P I A$; Schwabe and Trost, 1980$)$ as well as $\left[{ }^{3} \mathrm{H}\right] 1,3^{\prime}$-diethyl-8-phenylxanthine $\left({ }^{3} \mathrm{H}\right] \mathrm{DPX}$; Bruns et al., 1980) which, like other xanthines, is an antagonist of adenosine-stimulated adenylate cyclase (Londos and Wolff, 1977; van Calker et al., 1979; R. F. Bruns, personal communication). The binding of $\left[{ }^{3} \mathrm{H}\right] \mathrm{CHA},\left[{ }^{3} \mathrm{H}\right] 2$-chloradenosine, and $\left[{ }^{3} \mathrm{H}\right] \mathrm{PIA}$ labels $\mathrm{A}_{1}$ receptors, while in some species, $\left[{ }^{3} \mathrm{H}\right] \mathrm{DPX}$ binds to $\mathrm{A}_{1}$ receptors and it is possible that, in guinea pig brain, its binding is associated with $\mathrm{A}_{2}$ receptors (Bruns et al., 1980). Adenosine receptor binding is regulated by guanine nucleotides which selectively decrease the affinity of agonists for receptors (Bruns et al., 1980; Goodman et al., 1982). Adenosine receptors can be solubilized with retention in the soluble state both 
of binding activity and regulation by guanine nucleotides (Gavish et al., 1982). Adenosine receptor binding is most highly concentrated in brain tissue but can be readily detected in testes (Murphy and Snyder, 1981) and fat cell membranes (Trost and Schwabe, 1981).

Biochemical analysis of adenosine receptor hinding in different brain regions indicates an uneven distribution (Murphy and Snyder, 1982), suggesting that adenosine receptors might be highly localized in some brain areas. Preliminary studies in our own (Goodman and Snyder, 1981) and other laboratories (Lewis et al., 1981) have described autoradiographic analyses of $\left[{ }^{3} \mathrm{H}\right] \mathrm{CHA}$ binding in rat brain showing regional variations. In the present study, we report in detail the localization in rat brain of adenosine $\left(\mathrm{A}_{1}\right)$ receptors labeled with $\left[{ }^{3} \mathrm{H}\right] \mathrm{CHA}$.

\section{Materials and Methods}

The autoradiographic procedure used for this study involves incubating slide-mounted tissue sections with $\left[{ }^{3} \mathrm{H}\right] N^{6}$-cyclohexyladenosine $\left(\left[{ }^{3} \mathrm{II}\right] \mathrm{CIIA} ; 11.5 \mathrm{Ci} / \mathrm{mmol}\right.$; New England Nuclear Corp., Boston, MA) to label adenosine $\mathrm{A}_{1}$ receptors and apposing large, flexible, emulsioncoated coverslips to these tissues. The details of this procedure have been described previously (Young and Kuhar, 1979b). The general procedure used in these studies is stated briefly here.

Rat (Sprague-Dawley) brain lissue (perfused with $0.1 \%$ formaldehyde in isosmotic phosphate-buffered saline) was frozen rapidly onto brass microtome chucks, and 8$\mu \mathrm{m}$-thick (for autoradiography) or $10-\mu \mathrm{m}$-thick (for preliminary binding studies) sections were cut in a Harris cryostat-microtome (North Billerica, MA). The sections were thaw-mounted onto subbed slides (dipped in gelatin and chrome alum) and stored at $-20^{\circ} \mathrm{C}$ until used.

Receptor labeling procedure. Preliminary binding studies were performed by incubating slide-mounted tissue sections (two $10-\mu \mathrm{m}$ sections per slide) at room temperature $\left(22^{\circ} \mathrm{C}\right)$ with $\left.\Gamma^{3} \mathrm{H}\right] \mathrm{CHA}$ with or without $l$ - or $d$ $N^{6}$-phenylisopropyladenosine (l-PIA, Boehringer Mannheim; $d$-PIA, Warner-Lambert) in $170 \mathrm{~mm}$ Tris- $\mathrm{HCl}(\mathrm{pH}$ 7.4). Various incubation times, $\left[{ }^{3} \mathrm{H}\right] \mathrm{CHA}$ concentrations, and $l$ - or $d$-PIA concentrations were used as indicated under "Results." Prior to incubation with $\left[{ }^{3} \mathrm{H}\right] \mathrm{CHA}$, the tissue sections were incubated at room temperature for $20 \mathrm{~min}$ in buffer with $1 \mathrm{IU} / \mathrm{ml}$ of adenosine deaminase (Sigma Chemical Co., St. Louis, MO) to degrade endogenous adenosine. Unless stated otherwise, all incubations also included $1 \mathrm{IU} / \mathrm{ml}$ of adenosine deaminase. Following incubation with $\left[{ }^{3} \mathrm{H}\right] \mathrm{CHA}$, the tissue sections were washed in buffer at $0^{\circ} \mathrm{C}$ (two 5-min washes) to reduce nonspecific binding. Nonspecific binding values (blanks) were obtained by incubation in the presence of $5 \mu \mathrm{M} l$ PIA. In preliminary binding studies, the tissue sections were wiped off of the slide with a Whatman GF/B filter and placed in a scintillation vial with $10 \mathrm{ml}$ of Formula 947 (New England Nuclear Corp.), and the radioactivity was measured at $40 \%$ efficiency.

Autoradiographic studies. For autoradiography, the optimal conditions for labeling adenosine $\left(\mathrm{A}_{1}\right)$ receptors were used, $2 \mathrm{nM}\left[{ }^{3} \mathrm{H}\right] \mathrm{CHA}$ for $90 \mathrm{~min}$, to give a receptor occupancy of approximately $72 \%$. Adjacent blank slides (nonspecific) were generated by incubation with $5 \mu \mathrm{M} l$ PIA. Following the incubation, the slides were placed on a cold plate and the tissues were dried under a stream of cold, dry air. These slides were stored at $4^{\circ} \mathrm{C}$ until acidwashed coverslips coated with Kodak NTB-3 emulsion (1:1 with water) were glued in apposition to the tissue sections in the dark. After 6 to 8 weeks of exposure at $4^{\circ} \mathrm{C}$, the autoradiograms were developed, and the tissue was stained with pyronin $\mathrm{Y}$ as previously described (Young and Kuhar, 1979b).

Autoradiograms were screened with an Olympus darkfield/bright-field dissecting microscope (Olympus Optical Co., Ltd., New Hyde Park, NY) and a Leitz microscope with a mirror device was used to produce the darkfield photomicrographs (Bunton Instruments, Rockville, MD). The autoradiograms were evaluated with a Zeiss microscope equipped with a calibrated eyepiece grid to quantitate grain densities. The range of grain densities found ( 0 to 28 grains $/ 600 \mu \mathrm{m}^{3}$ ) was linear with tissue radioactivity (Unnerstall et al., 1981). Blank slides had a uniform grain density of $2.2 \pm 0.2$ grains $/ 600 \mu \mathrm{m}^{3}$. The grain densities defined in this paper as significant were greater than or equal to $3.7 \pm 0.3$ grains $/ 600 \mu \mathrm{m}^{3}(p<$ 0.005 ). All of the autoradiographic results reported have been found in several sections from at least two animals. This procedure has been shown to cause no positive or negative chemography (Young and Kuhar, 1979b).

\section{Results}

Biochemical properties of $\left[{ }^{3} \mathrm{H}\right] \mathrm{CHA}$ binding to brain slices. The labeling of receptors for autoradiographic analysis is done on thin brain slices. It is important to ensure that the binding of the ${ }^{3} \mathrm{H}$-ligand to these slices involves the same receptors as when binding is assayed in brain membranes in homogenate preparations. $\left[{ }^{3} \mathrm{H}\right]$ CHA binding to rat brain slices is saturable (Fig. $1 A$ ). Total binding is at least 20 times the nonspecific binding assayed in the presence of $5 \mu \mathrm{M} l$-PIA. Such low levels of nonspecific binding facilitate optimal autoradiographic analysis, ensuring that essentially all of the visualized autoradiographic grains will be associated with specific adenosine receptor binding sites.

Scatchard analysis of the binding indicates a dissociation constant $\left(K_{D}\right)$ of $0.77 \mathrm{nM}$ and a maximal number of binding sites $\left(B_{\text {maxa }}\right)$ of $423 \mathrm{fmol} / \mathrm{mg}$ of protein (Fig. $1 A$ ). These $K_{D}$ and $B_{\max }$ values are about the same as in rat brain (Murphy and Snyder, 1982) and bovine brain homogenates, but the $K_{D}$ is somewhat lower than in guinea pig brain (Bruns et al., 1980).

To ensure that the binding involves the same sites labeled in homogenates, we evaluated the displacement of $\left[{ }^{3} \mathrm{H}\right] \mathrm{CHA}$ binding by $l$-PIA and $d$-PIA (Fig. $1 B$ ). $l$-PIA inhibits specific binding by $50 \%$ at $1 \mathrm{nM}$, about 100 times more potently than $d$-PIA. The potency of $l$-PIA and the stereoselectivity of the PIA isomers closely resemble what we have found for $A_{1}$ receptors in binding assays using homogenates of guinea pig, bovine, and rat brain (Murphy and Snyder, 1982). Binding reaches equilibrium at about $70 \mathrm{~min}$. $\Lambda \mathrm{fter}$ a 10 -min wash in $50 \mathrm{ml}$ of Tris buffer at $0^{\circ} \mathrm{C}$, more than $95 \%$ of the initial specific binding remains (data not shown). Failure to include adenosine deaminase in the incubation medium reduces specific binding by $50 \%$ (data not shown).

Autoradiographic studies. One of the highest densities of $\left[{ }^{3} \mathrm{H}\right] \mathrm{CHA}$ grains occurs in the hippocampus (Fig. 2). 

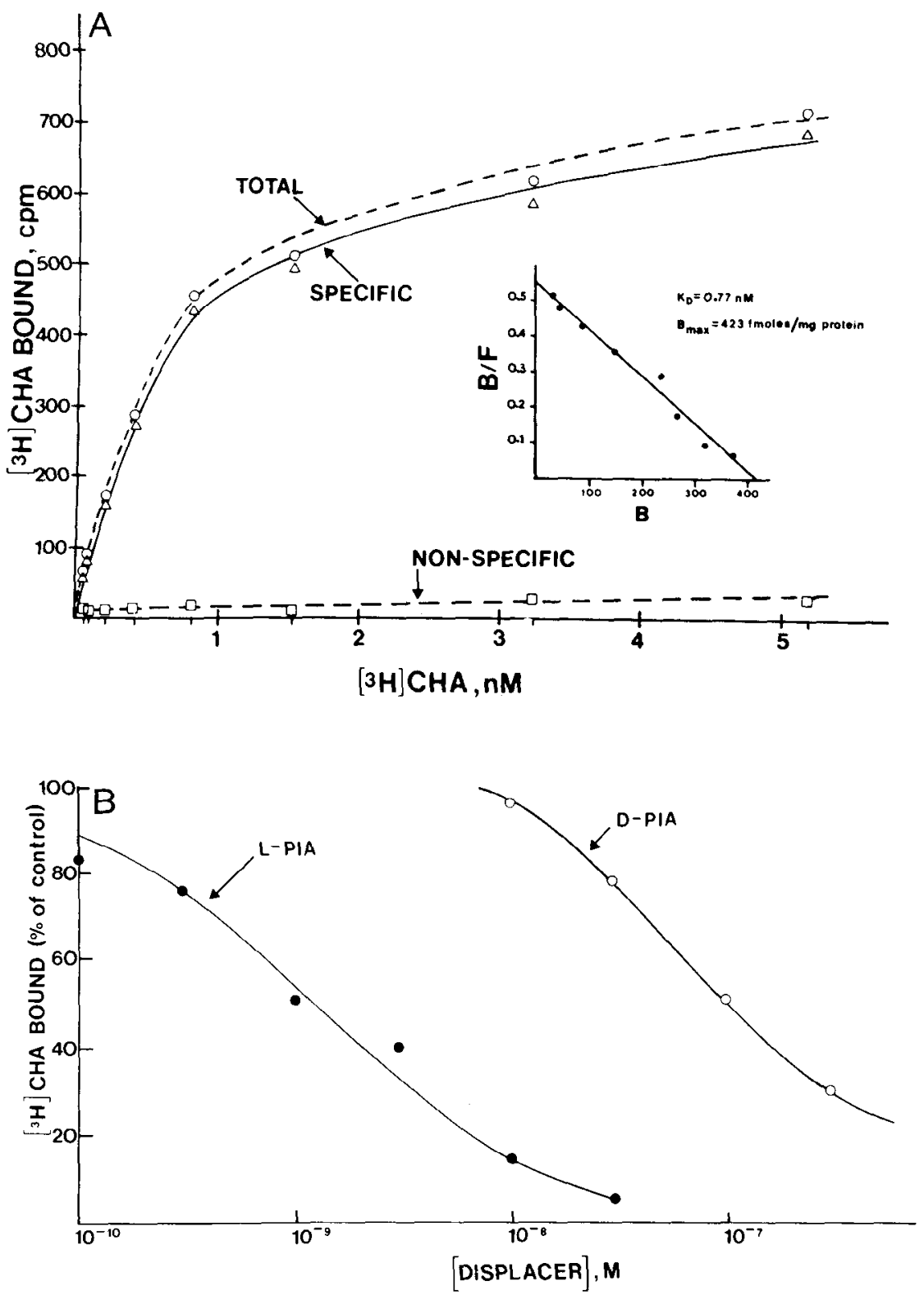

Figure 1. A, Saturation of $\left[{ }^{3} \mathrm{H}\right] \mathrm{CHA}$ binding in tissue sections. The tissue sections were incubated with varying concentrations of $\left[{ }^{3} \mathrm{H}\right] \mathrm{CHA}$ in $0.17 \mathrm{~m}$ Tris- $\mathrm{HCl}, \mathrm{pH} 7.4$, with or without $5 \mu \mathrm{M} l$-PIA for $90 \mathrm{~min}$ at room temperature (about $22^{\circ} \mathrm{C}$ ). The sections then were rinsed in two 5 -min washes at $0^{\circ} \mathrm{C}$, wiped off, and counted as described in text. The results and the means of triplicate determinations and this experiment were repeated two times. The inset is a Scatchard plot of these data. $B$, Displacements of $\left[{ }^{3} \mathrm{H}\right] \mathrm{CHA}$ binding in tissue sections. Tissues were incubated and processed as described in $A$ and in the text with $1.0 \mathrm{nM}\left[{ }^{3} \mathrm{H}\right] \mathrm{CHA}$ and varying concentrations of $l$ or $d$-PIA. The rcsults are reported as the percentage of control specific binding and are the means of triplicate determinations repeated two times.

Grain densities are highest in the molecular and polymorphic layers, while very low levels are found over the pyramidal cell layer. There does not appear to be any selective localization of grains within the various subdivisions of the hippocampus. Grain density within the hippocampus is somewhat higher than in the dentate gyrus, which has a similar distribution.

The thalamus also displays very high grain densities in most of its nuclei. There are some variations, with the medial, gelatinosus, and lateral nuclei having higher grain densities than the ventral nuclei of the thalamus. Among the diencephalic structures, one of the highest densities occurs in the medial geniculate body which is comparable in density to the medial and gelatinosus nuclei of the thalamus (Fig. 3).

In contrast to the high densities of receptors in the hippocampus and thalamus, the hypothalamus appears almost devoid of adenosine receptors. We explored nu- 


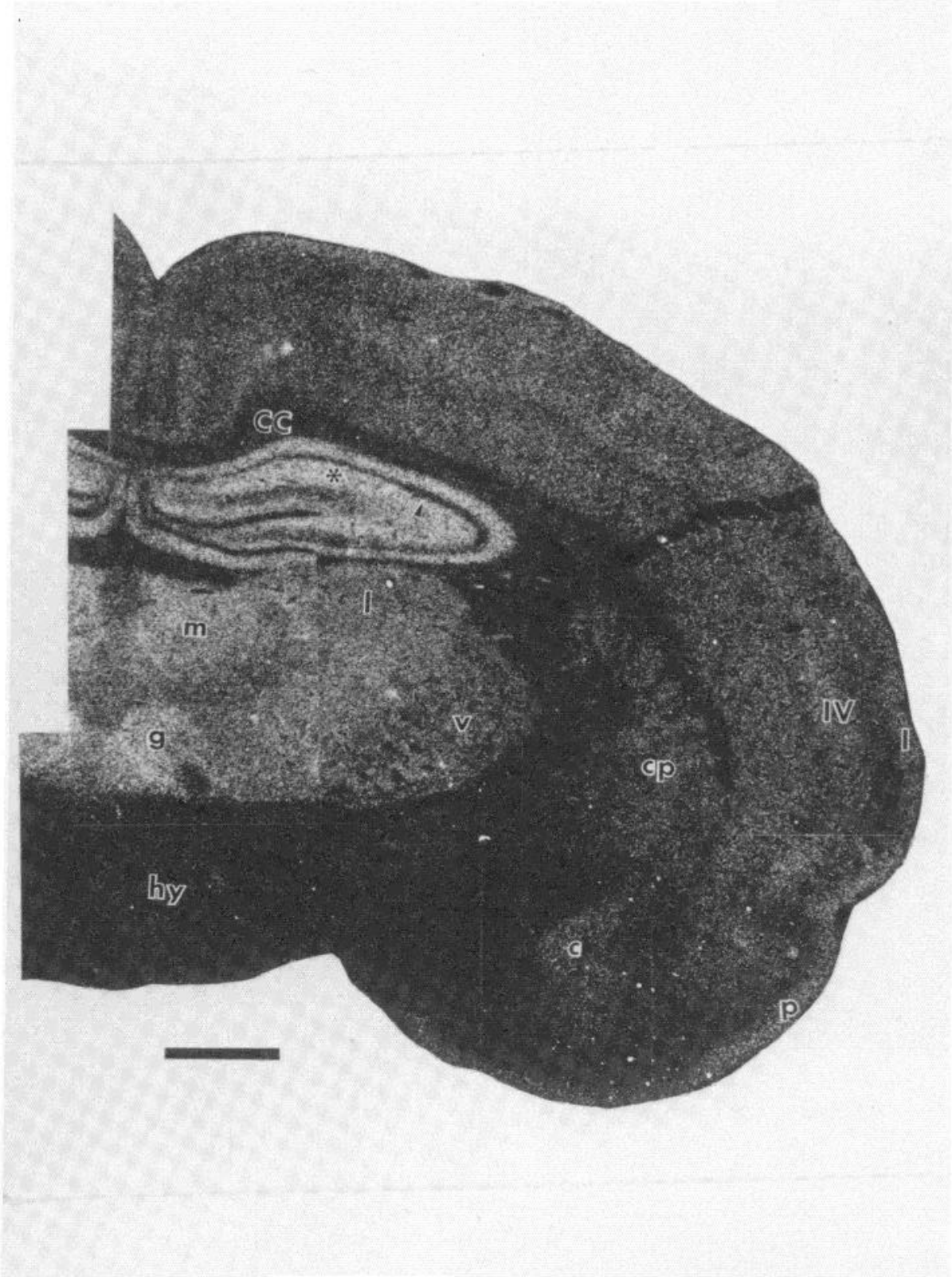

Figure 2. Dark-field photomicrograph of adenosine $\left(A_{1}\right)$ receptors in rat brain, A 4620 $\mu$ (Konig and Klippel, 1963). Tissue sections were incubated in $2.0 \mathrm{~nm}\left[{ }^{3} \mathrm{H}\right] \mathrm{CHA}$ at room temperature (about $22^{\circ} \mathrm{C}$ ) for $90 \mathrm{~min}$ and then processed as described in the text. Particularly high concentrations of $\mathrm{A}_{1}$ receptors are seen in the molecular (*) and polymorphic layers of the hippocampus and dentate gyrus and in the medial, gelatinosus, and lateral nuclei of the thalamus $\left(m, g\right.$, and $l$ ). Other areas with moderate $\mathrm{A}_{1}$ receptor densities include the first $(I)$ and fourth $(I V)$ layers of the cerebral cortex, the piriform $(p)$ cortex, the caudate-putamen $(c p)$, the central nucleus of the amygdala $(c)$, and the ventral thalamus $(v)$. The hypothalamus $(h y)$ and pyramidal cell layer (arrowhead) of the hippocampus have negligible receptor densities, while the corpus callosum $(c c)$ has a low but significant concentration (see "Materials and Methods"). Bar, $1000 \mu \mathrm{m}$.

merous levels corresponding to all of the major subdivisions of the hypothalamus and have failed to detect substantial receptor density in any portion of the hypothalamus.

In contrast to the relative homogeneity of grain distribution throughout the thalamus, there are marked variations within the amygdala. Moderate receptor density occurs within the central nucleus, while only negligible, if any, levels are observed in other nuclei of the amygdala. In examining several levels, we have failed to find evidence of adenosine receptor labeling in the cortical, medial, basal, and lateral nuclei. Unlike most other white matter areas examined, the corpus callosum has a low but significant density of adenosine receptors. 


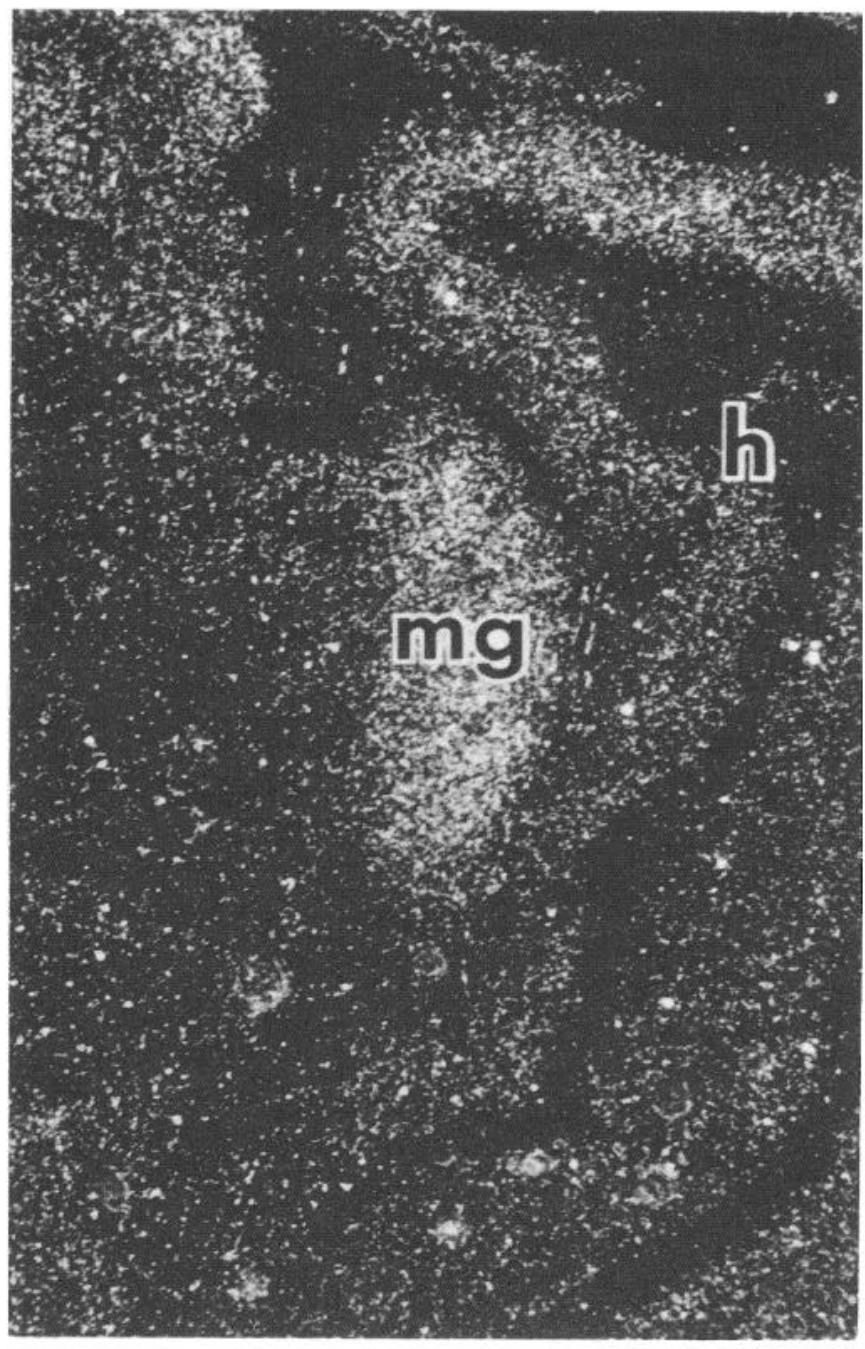

Figure 3. Dark-field photomicrograph of adenosine $\left(\mathrm{A}_{1}\right)$ receptors in rat brain, A $1270 \mu$ (Konig and Klippel, 1963). Adenosine $\left(A_{1}\right)$ receptors were labeled as described in the legend to Figure 2 and in the text. Note the much higher $A_{1}$ receptor density in the medial geniculate body $(m g)$ versus the adjacent midbrain. $h$, Hippocampus. Bar, $1000 \mu \mathrm{m}$.

Within the cerebral cortex, receptor localization varies with different layers (Fig. 4). Fairly substantial adenosine receptor densities occur in layers I, IV, and VI, while lower levels are detected in layers II, III, and V. A similar pattern and density of grains occurs in frontal, parietal, temporal, occipital, and piriform cortices. Since the piriform cortex has fewer layers than the cerebral cortex, the layering of grains observed in other parts of the cerebral cortex is not apparent in the piriform cortex.

Fairly homogeneous and moderate-to-low grain density occurs throughout the caudate-putamen. The closely adjacent nucleus accumbens and olfactory tubercle have somewhat higher grain densities. Though not depicted in the figures, the lateral septum has fairly substantial grain densities, slightly higher than those found in the olfactory tubercle and central nucleus of the amygdala.

The highest density of adenosine receptors that we have observed in rat brain occurs in the molecular layer of the cerebellum (Fig. 5A). The granule cell layer displays moderate grain density. The high grain density of the molecular layer occurs in all subdivisions of the cerebellum, including the vermis and all of the folia. The white matter of the cerebellar peduncles contains an extremely low density as do the facial nerve and many other white matter areas, such as the anterior commissure.

Most portions of the medulla display adenosine receptor grains but substantially less than in the molecular layer of the cerebellum. Of the brain stem areas evaluated, the highest density occurs in the nucleus of the spinal tract of the trigeminal nerve. In the spinal cord, a high density of receptors occurs in the substantia gelatinosa.

Adjacent sections of all brain areas studied incubated in the presence of $5 \mu \mathrm{M}$ unlabeled $l$-PIA display negligible grain density, ensuring that the observed autoradiographic grains represent specific saturable binding sites (for cerebellum, see Fig. 5B).

Light-field micrographs under high power (Fig. 6) facilitate an evaluation of the structures labeled with $\left[{ }^{3} \mathrm{H}\right]$ CHA. Cerebellar grain density is clearly highest over the molecular layer, though substantial numbers of grains occur over the granule cell layer, with much less grain density over the white matter. Sections incubated in the presence of $5 \mu \mathrm{M} l$-PIA (Fig. $6 \mathrm{C}$ ) display negligible grain density in any of these areas, including the white matter. This suggests that the low levels of grains over the white matter do reflect the binding of $\left[{ }^{3} \mathrm{H}\right] \mathrm{CHA}$ to specific adenosine receptors.

Though grain density tends to be fairly homogeneous throughout the gray matter of the brain stem, there are some distinctions. The superficial gray layer of the superior colliculus does display substantially higher levels than most other portions of the brain stem (Fig. 7). At the level depicted in Figure 8, the pontine nucleus contains the highest grain density and the periaqueductal gray and inferior colliculus have a higher concentration of receptors than other portions of the brain stem reticular formation. As observed for most other white matter regions, the decussation of the superior cerebellar peduncle and the pyramidal tract have extremely low grain density.

\section{Discussion}

$\left[{ }^{3} \mathrm{H}\right] \mathrm{CHA}$ labels adenosine receptors of the $\mathrm{A}_{1}$ type (Bruns et al., 1980; Murphy and Snyder, 1982). The similar high affinity of $\left[{ }^{3} \mathrm{H}\right] \mathrm{CHA}$ in binding to thin rat brain slices and the potency and stereoselectivity of PIA isomers indicate that binding under the conditions employed for autoradiography involves the same sites as in homogenate studies. The autoradiographic grains observed in the present studies could be displaced almost entirely by $5 \mu \mathrm{M} l$-PIA. Taken together, these data indicate that the autoradiographic grains visualized after $\left[{ }^{3} \mathrm{H}\right] \mathrm{CHA}$ application to brain slices represent adenosine $\mathrm{A}_{1}$ receptors (Table I). These localizations are very similar to the preliminary results recently reported by Lewis et al. (1981), though detailed comparisons with preliminary observations are not readily performed. 


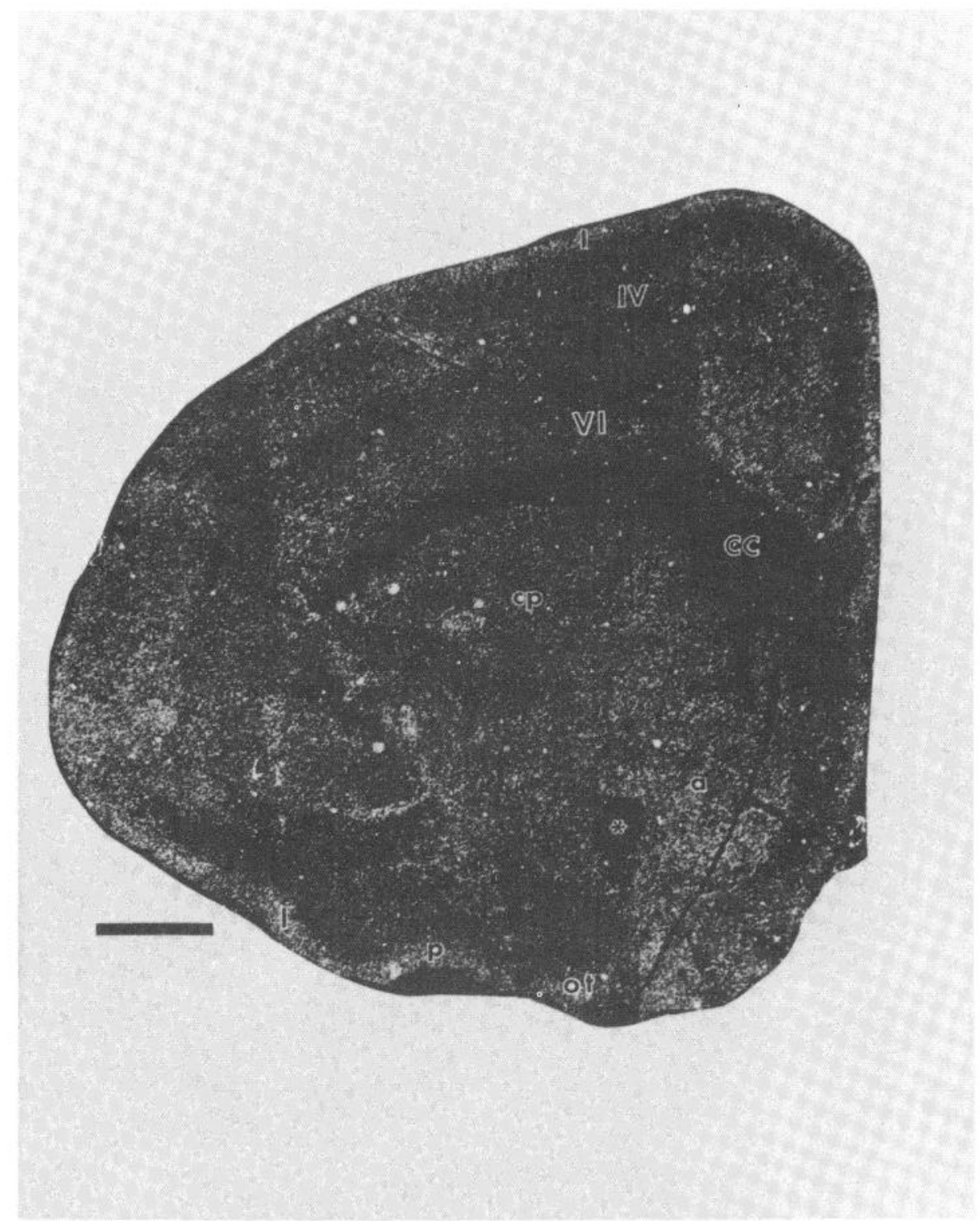

Figure 4. Dark-field photomicrograph of adenosine $\left(\mathrm{A}_{1}\right)$ receptors in rat brain, A $9410 \mu$ (Konig and Klippel, 1963). Adenosine $\left(\mathrm{A}_{1}\right)$ receptors were labeled as described in the legend to Figure 2 and in the text. At this level, no high concentrations of $A_{1}$ receptors are seen, but several areas have moderate densities. These areas include, in order of descending densities, the piriform cortex $(p)$, olfactory tubercle $(o t)$, first $(I)$, fourth $(I V)$, and sixth $(V I)$ layers of the cerebral cortex, nucleus accumbens $(a)$, and caudate-putamen $(c c)$. Low receptor densities are found in layers II, III, and V of the cerebral cortex, very low densities are seen in the corpus callosum $(c c)$, and negligible amounts appear in the anterior commissure (*). Bar, $500 \mu \mathrm{m}$.

The autoradiographic localizations of adenosine receptors may provide clues to the functions of adenosine within the brain. In behavioral studies, very low doses of $l$-PIA depress locomotor activity stereoselectively, with $l$-PIA about 50 -fold more potent than $d$-PIA (Snyder et al., 1981). Moreover, xanthines, which are potent in blocking adenosine receptors, also antagonize the behavioral actions of $l$-PIA and, in some cases, transform them into stimulant effects. It is not clear whether the behavioral effects are due largely to $A_{1}$ receptors, though this seems to be a good possibility. If $l$-PIA exerts its depressant actions via adenosine $A_{1}$ receptors, then the recep- tors visualized in the present study are relevant to such effects. Some limited structure-activity analysis indicates that the neurophysiologic depressant effects of adenosine on cell firing in various brain areas also involve $\mathrm{A}_{1}$ receptors (Phillis et al., 1979).

The cerebellum displayed the highest density of adenosine receptors, which was most marked in the molecular layer. Since the cerebellum has a limited number of well defined cell types, it would be of interest to determine whether adenosine receptors are associated with only a single neuronal class in the cerebellum. Using neurologically mutant mice, we have obtained evidence that aden- 

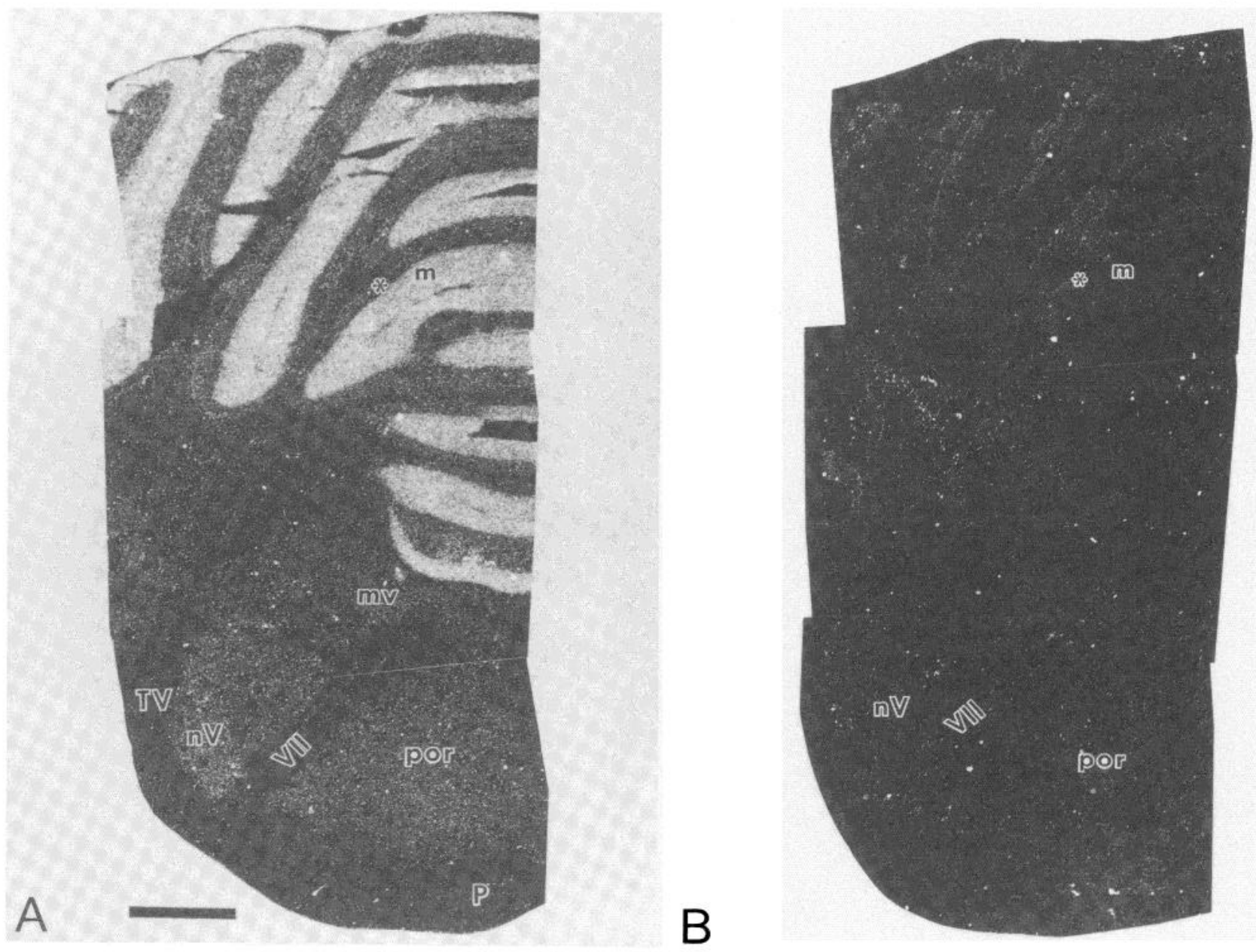

Figure 5. Dark-field photomicrographs of $\left[{ }^{3} \mathrm{H}\right] \mathrm{CHA}$ binding in rat brain, $\mathrm{P} 3.4 \mathrm{~mm}$ (Palkovitz and Jacobowitz, 1974). A, Adenosine $\left(\mathrm{A}_{1}\right)$ receptors labeled as described in the legend to Figure 2 and in the text. The highest $\mathrm{A}_{1}$ receptor density of any brain area studied occurs at this level throughout the molecular layer $(m)$ of the cerebellum. Moderate densities occur in the granule cell layer $(*)$ of the cerebellum and a low density is seen in the nucleus of the spinal tract of the trigeminal nerve $(n V)$. Throughout the brain stem gray matter, a significant density (see "Materials and Methods") of $A_{1}$ receptors is found, for example, in the pontine reticular formation (por) and the medial vestibular nucleus $(m v)$ at this brain level. White matter areas, including the cerebellar white matter, the spinal tract of the trigeminal nerve $(T V)$, the pyramidal tract $(P)$, and the facial nerve $(V I I)$, contain negligible receptor densities. Bar, $1000 \mu \mathrm{m}$. B, Photomicrograph of an adjacent thin brain section incubated with 2.0 nM $\left[{ }^{3} \mathrm{H}\right] \mathrm{CHA}$ in the presence of $5 \mu \mathrm{M} l$-PIA to generate a blank (nonspecific binding). The grain density is uniform throughout and approximately equal to that found in the white matter areas in $A$.

osine receptors in the cerebellum are localized to granule cells, particularly their parallel fibers and terminals in the molecular layer (R. R. Goodman and S. H. Snyder, manuscript in preparation). Thus, weaver mice, which lack granule cells, are devoid of cerebellar adenosine receptors. In the reeler mouse, whose cerebellar layers are disoriented, there is a corresponding disorientation of adenosine receptor grains, fitting with a localization to granule cell parallel fibers. Nervous mice, which are devoid of Purkinje cells, have normal levels of adenosine receptor grains.

Granule cells are the sole excitatory neurons of the cerebellum. The localization of adenosine receptors to their processes suggests that adenosine might influence the release of the excitatory transmitter, presumably glutamic acid, from the granule cells (Young et al., 1974). In most systems, adenosine inhibits the release of neurotransmitters (Miyamoto and Breckenridge, 1974; Israel et al., 1977; Michaelis et al., 1979; Hollins and Stone,
1980). There is evidence that the inhibition of neuronal firing by adenosine is presynaptic, involving inhibition of the release of the excitatory transmitter (Phillis and Wu, 1981). This would fit well with a localization of adenosine receptors to axons and terminals of the excitatory parallel fibers in the cerebellum. Lesion studies in various parts of the brain may clarify the localization of adenosine receptors in other areas (R. R. Goodman and S. H. Snyder, manuscript in preparation).

The behavioral depression elicited by $l$-PIA occurs over a wide range of doses, with no lethality even at high doses and with no evident hypnotic actions despite the reduction in locomotor activity (Snyder et al., 1981). This behavioral pattern resembles that elicited by benzodiazepines. It has been suggested that benzodiazepines might exert behavioral effects through adenosine systems, perhaps by inhibiting adenosine uptake (Phillis et al., 1980) and that endogenous purines, including adenosines, interact with benzodiazepine receptors (Marangos et al., 


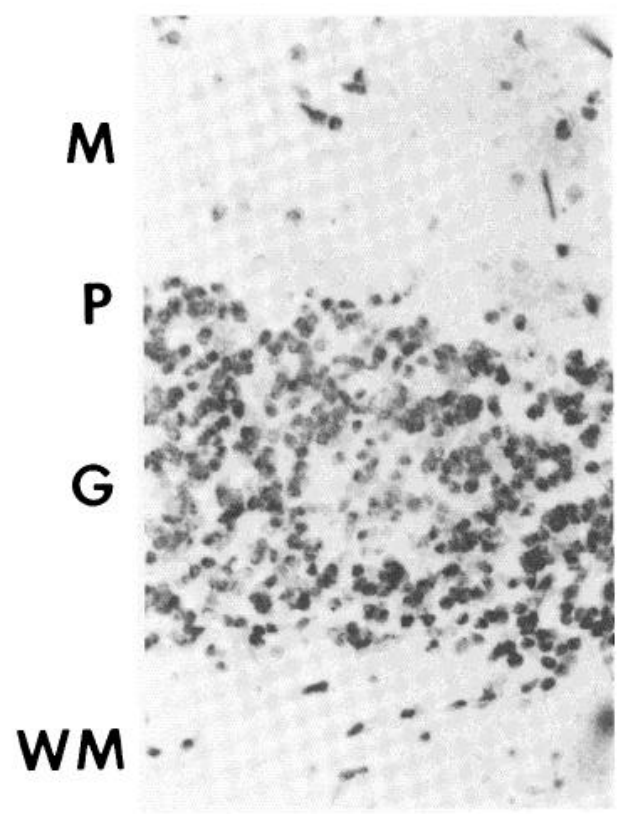

A

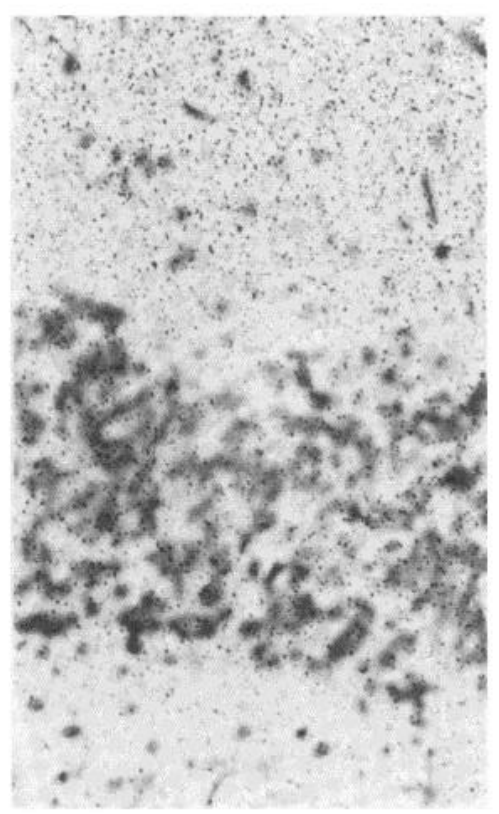

B

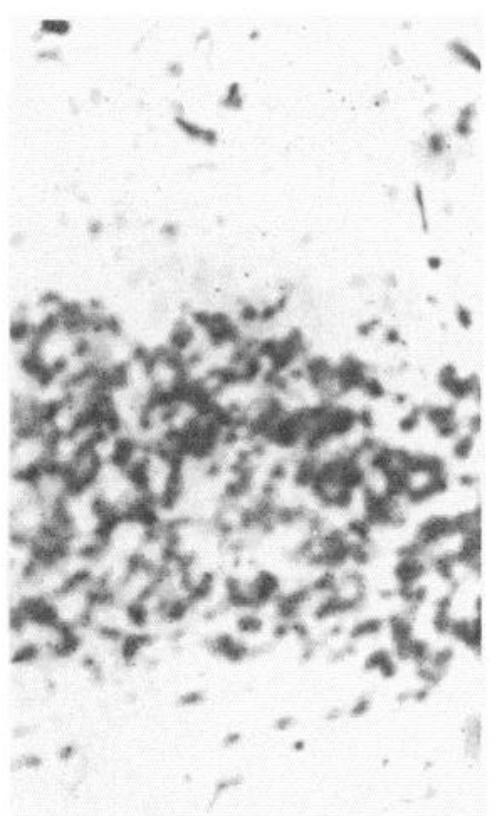

C

\section{$60 \mu \mathrm{m}$}

Figure 6. High power bright-field photomicrographs of rat cerebellum. A, Tissue section incubated with $\left[{ }^{3} \mathrm{H}\right] \mathrm{CHA}$ to label $\mathrm{A}_{1}$ receptors as detailed in the legend to Figure 2 and in the text. This photomicrograph is focused on the tissue to show the molecular layer $(M)$, Purkinje cell layer $(P)$, granule cell layer $(G)$, and white matter $(W M)$. $B$, The same tissue section as $A$ but focused on the emulsion to show the grain (receptor) densities. Notice the very high grain density over the molecular layer, moderate density over the granule cell layer, and low density over the granule cell layer and the white matter. $C$, Adjacent thin section incubated in the presence of $5 \mu \mathrm{m} l$-PIA to generate a blank (nonspecific binding). Note the uniform and extremely low grain density throughout.

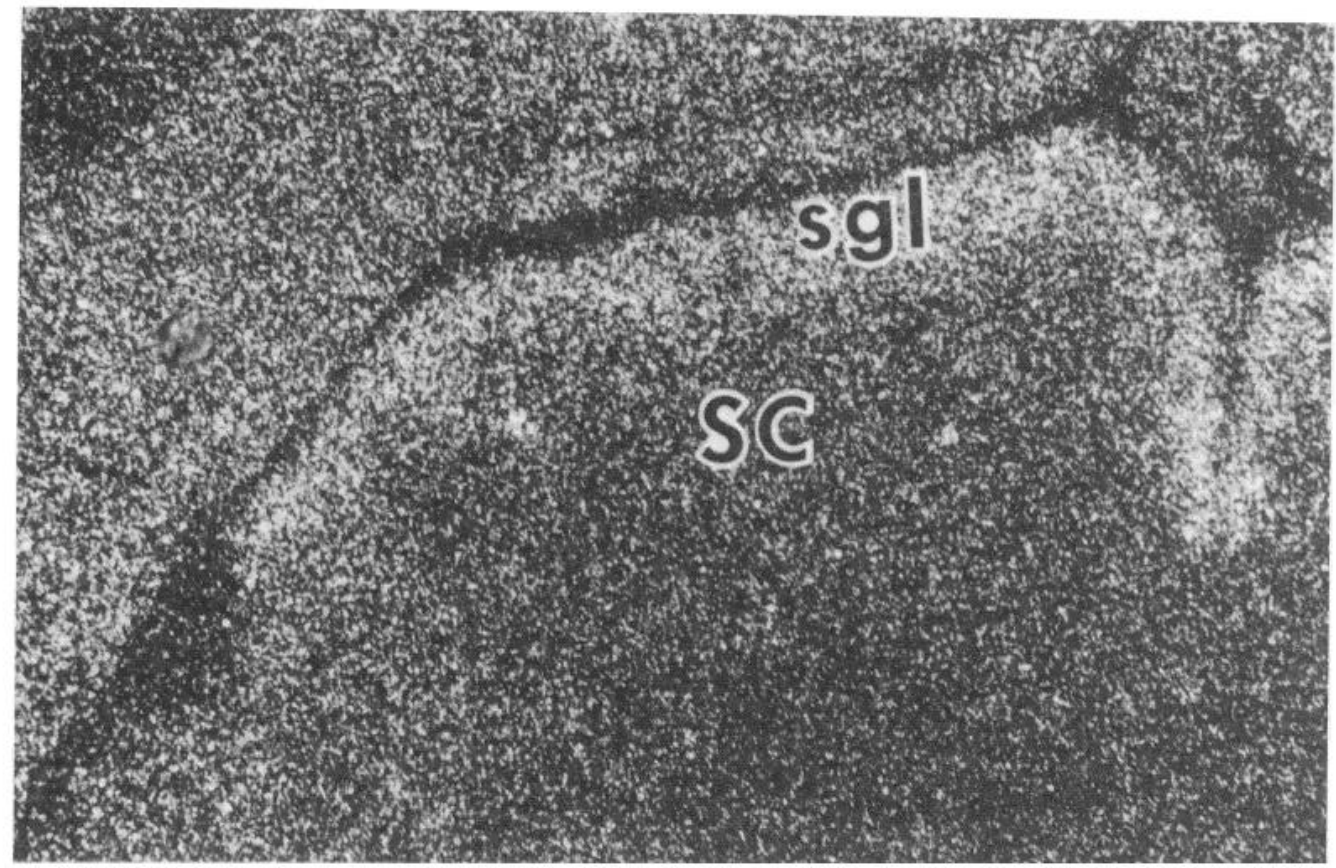

Figure 7. High power dark-field photomicrograph of adenosine $\left(\mathrm{A}_{1}\right)$ receptors in the superior colliculus ( $S C$ ). $\mathrm{A}_{1}$ receptors were labeled as described in the legend to Figure 2 and in the text. A moderately high $\mathrm{A}_{1}$ receptor density is seen in the superficial gray layer $(\mathrm{sgl})$, which contrasts with the low densities found in adjacent brain areas. Bar, $500 \mu \mathrm{m}$. 


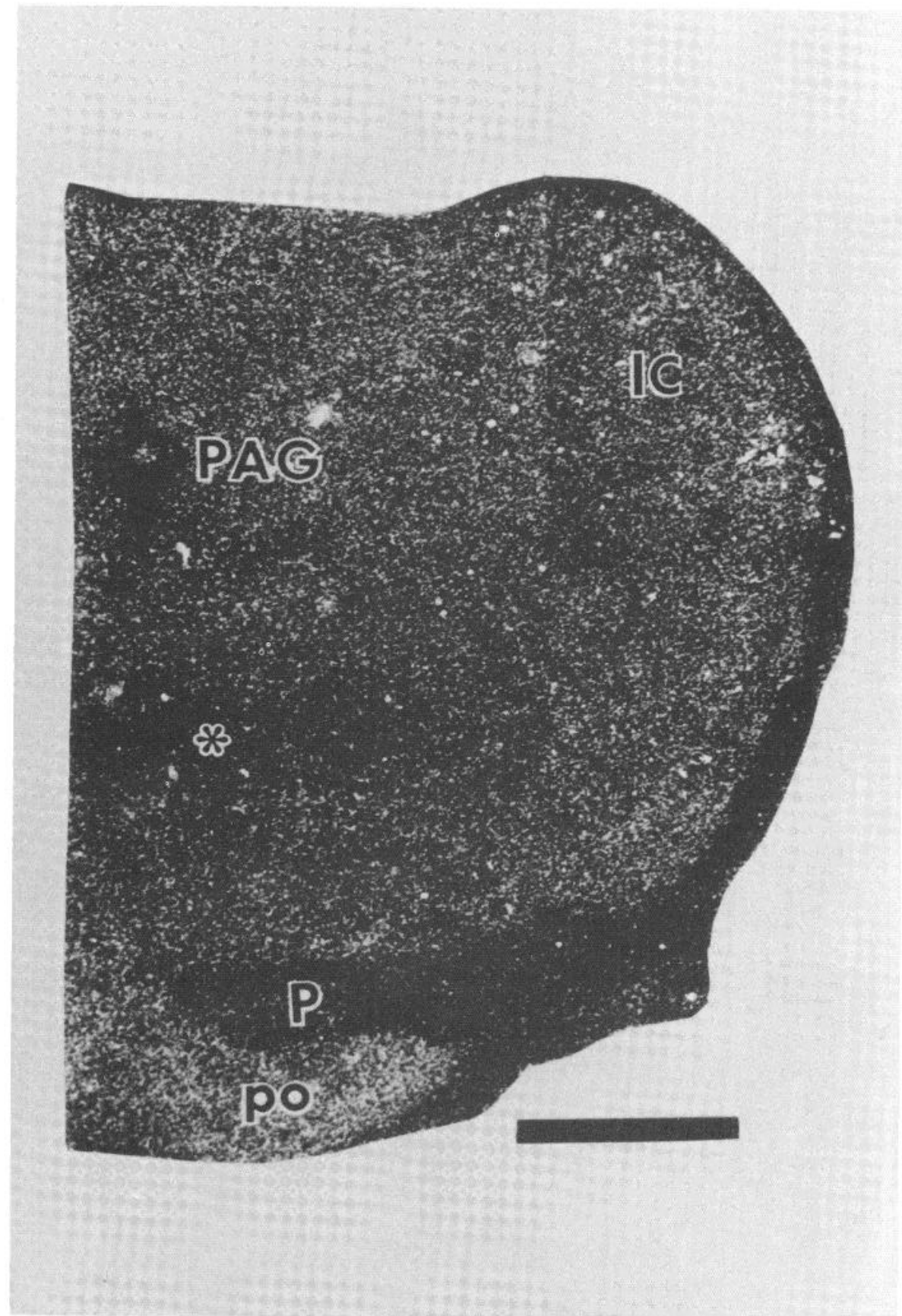

Figure 8. Dark-field photomicrograph of adenosine $\left(\mathrm{A}_{1}\right)$ receptors in the rat brain, P $0.1 \mathrm{~mm}$ (Palkovitz and Jacobowitz, 1974). At this brain level, the highest receptor density is a moderate density found in the pontine nuclei $(p o)$. Moderate densities also occur throughout the periaqueductal gray $(P A G)$, inferior colliculus $(I C)$, and reticular formation. White matter areas at this level, including the pyramidal tract $(P)$ and the decussation of the superior cerebellar peduncle $(*)$, have negligible receptor density. Bar, $1000 \mu \mathrm{m}$.

1979). Interestingly, in the cerebellum, benzodiazepine receptors also are concentrated in the molecular layer (Young and Kuhar, 1980). However, there are some marked discrepancies between the localizations of benzodiazepine and adenosine receptors. For instance, the hypothalamus, with one of the highest densities of benzodiazepine receptors, is virtually devoid of adenosine receptors. The thalamus tends to be low in benzodiaze- pine receptors but has very high densities of adenosine receptors. Benzodiazepine receptors are more highly concentrated in the dentate gyrus than in the hippocampus, while the reverse is true for adenosine receptors. Within the amygdala, benzodiazepine receptors are most concentrated in the posterolateral nucleus, with very few receptors in the central nucleus, while the reverse holds for adenosine receptors. It is interesting to note, however, 


\section{TABLE I}

Regional adenosine $\left(A_{1}\right)$ receptor densities

Autoradiograms (generated as described in the legend to Fig. 2 and in the text) were evaluated at $\times 1000$ with a Zeiss microscope equipped with a calibrated eyepiece grid to quantitate grain densities. Grain densities in each region represent the means of grains counted in six $600-\mu \mathrm{m}^{3}$ areas in representative sections from each of two animals. Brain regions were grouped into four different density ranges: high, 18 to 28 grains $/ 600 \mu \mathrm{m}^{3}$; moderate, 11 to 17.9 grains $/ 600 \mu \mathrm{m}^{3}$; low, 5 to 10 grains $/ 600 \mu \mathrm{m}^{3}$; and very low, 0 to 4.7 grains $/ 600 \mu \mathrm{m}^{3}$. Nonspecific binding (sections incubated with $5 \mu \mathrm{M} l$-PIA) gave uniform densities equal to or less than 2.2 grains $/ 600 \mu \mathrm{m}^{3}$. Within each group, the regions are listed in order of decreasing densities. All means varied by less than $10 \%$. Grain densities within this range are linear with radioactivity (Unnerstall et al., 1981).

\begin{tabular}{|c|c|c|c|}
\hline High & Moderate & Low & Very Low \\
\hline $\begin{array}{l}\text { Cerebellum } \\
\text { Molecular } \\
\text { layer } \\
\text { Hippocampus/ } \\
\text { dentate } \\
\text { gyrus } \\
\text { Molecular } \\
\text { layers } \\
\text { Polymorphic } \\
\text { layers } \\
\text { Medial genicu- } \\
\text { late body } \\
\text { Thalamic nuclei } \\
\text { Medial } \\
\text { Gelatinosus } \\
\text { Lateral } \\
\text { Lateral septum } \\
\text { Spinal cord } \\
\text { Substantia ge- } \\
\text { latinosa }\end{array}$ & $\begin{array}{l}\text { Superior collic- } \\
\text { ulus } \\
\text { Superficial } \\
\text { layer } \\
\text { Piriform cortex } \\
\text { Olfactory tuber- } \\
\text { cle } \\
\text { Cerebral cortex } \\
\text { Layers I, IV, } \\
\text { and VI } \\
\text { Cerebellum } \\
\text { Granule cell } \\
\text { layer } \\
\text { Nucleus accum- } \\
\text { bens } \\
\text { Caudate-puta- } \\
\text { men } \\
\text { Amygdala } \\
\text { Central nu- } \\
\text { cleus } \\
\text { Thalamic nuclei } \\
\text { Ventral }\end{array}$ & $\begin{array}{l}\text { Cerebral cortex } \\
\text { Layers II, III, } \\
\text { and V } \\
\text { Trigeminal } \\
\text { nerve } \\
\text { Spinal trace } \\
\text { nucleus } \\
\text { Pontine nuclei } \\
\text { Inferior collic- } \\
\text { ulus } \\
\text { Periaqueductal } \\
\text { gray } \\
\text { Corpus callosum } \\
\text { Reticular forma- } \\
\text { tion } \\
\text { Pontine } \\
\text { Medullary }\end{array}$ & $\begin{array}{l}\text { Hypothalamus } \\
\text { Anterior com- } \\
\text { missure } \\
\text { Cerebellum } \\
\text { White matter } \\
\text { Superior cere- } \\
\text { bellar pe- } \\
\text { duncle }^{a} \\
\text { Pyramidal }^{\text {Pyact }} \\
\text { tract }^{a} \\
\text { Trigeminal }^{\text {nerve }} \\
\text { npinal tract }^{a} \\
\text { Spinal tract }^{a}\end{array}$ \\
\hline
\end{tabular}

${ }^{a}$ No significant differences (see "Materials and Methods").

that the hypothalamus has high levels of 2-chloroadenosine binding (Williams and Risley, 1980; Phillis and Wu, 1981). Inclusion of thalamic tissue, which has high $\left[{ }^{3} \mathrm{H}\right]$ CHA binding, in these dissections could account for the discrepancies.

Although the histochemical localization of adenosine to specific neuronal systems has not been possible, several laboratories have reported the specific neuronal histochemical localization of the adenosine-generating enzyme 5'-nucleotidase (Scott, 1964, 1965, 1967; Schubert et al., 1979). Many areas, particularly synaptic regions, contain high 5 '-nucleotidase activities and a comparison with adenosine $\left(A_{1}\right)$ receptor distribution indicates several interesting similarities (Table II). The molecular layer of the mouse cerebellum has high $5^{\prime}$-nucleotidase activity in anteroposteriorly oriented bands, and this region in the rat displayed the highest $\mathrm{A}_{1}$ receptor density, although it was distributed uniformly in the molecular layer. Other areas with high 5'-nucleotidase activities in the mouse brain include the corpus striatum and layers I and IV of the perirhinal cortex, areas in which we find moderate $A_{1}$ receptor densities. In the rat, high $5^{\prime}$-nucleotidase activity occurs in the molecular and polymorphic layers of the dentate gyrus and hippocampus (regio su- perior), while in regio inferior, activity is largely confined to juxtapyramidal cell areas (Schubert et al., 1979). A high $A_{1}$ receptor density is seen throughout these areas, though no difference is noted between regio superior and regio inferior. Studies of the subcellular (Pilcher and Jones, 1970; Marani, 1977) and electron microscopic (Marani, 1977; Bernstein et al., 1978) localizations of $5^{\prime}$ nucleotidase suggest that it is enriched in synaptosomes and axoplasm at axodendritic synapses.

These similarities suggest that conceivably "adenosinergic" neurons exist in which 5 '-nucleotidase activity generates synaptically active adenosine which interacts with the $A_{1}$ receptors that we have localized. However, discrepancies between adenosine receptors and $5^{\prime}$-nucleotidase localization might argue against such an association. These discrepancies could be due to several factors. 5 '-Nucleotidase might exist in several "pools," only one of which synthesizes the hypothesized "neuromodulator pool" of adenosine. This would go along with the many metabolic roles of adenosine generated by $5^{\prime}$-nucleotidase. Thus, while 5'-nucleotidase is primarily a neuronal membrane marker, it also occurs in highly purified myelin (Cammer et al., 1980). Enzyme activity in myelin could explain the substantial $5^{\prime}$-nucleotidase levels in the corpus callosum and brain stem.

Another explanation of the differences in adenosine receptor and 5'-nucleotidase localizations may relate to the observations that neurotransmitter receptors often

\section{TABLE II}

Regional distributions of $5^{\prime}$-nucleotidase and adenosine $A_{1}$ receptors

Comparison of the regional distribution of 5 '-nucleotidase activity found in mouse (Scott, 1964, 1965, 1967) and rat (Bernstein et al., 1978; Schubert et al., 1979) brain with the regional $A_{1}$ receptor densities reported here in rat brain.

\begin{tabular}{|c|c|c|}
\hline Brain Regions & $\begin{array}{c}5 \text {-Nucleotidase Activity } \\
\text { (Mouse) }\end{array}$ & $\begin{array}{c}\text { A }_{1} \text { Receptor Density } \\
\text { (Rat) }\end{array}$ \\
\hline \multicolumn{3}{|l|}{ Cerebellum } \\
\hline Molecular layer & High (bands) & High (uniform) \\
\hline Granule cell layer & Low & Moderate \\
\hline \multicolumn{3}{|l|}{ Hippocampus } \\
\hline Molecular layer & $\begin{array}{l}\text { High }^{a} \text { (regio superior } \\
\gg \text { regio inferior) }\end{array}$ & $\begin{array}{l}\text { High (regio supe- } \\
\text { rior = regio infe- } \\
\text { rior) }\end{array}$ \\
\hline Polymorphic layer & $\operatorname{High}^{a}$ & High \\
\hline \multicolumn{3}{|l|}{ Dentate gyrus } \\
\hline Molecular layer & $\operatorname{High}^{a}$ & High \\
\hline Polymorphic layer & $\operatorname{High}^{a}$ & High \\
\hline Corpus striatum & Very high & Moderate \\
\hline \multicolumn{3}{|l|}{ Perirhinal cortex } \\
\hline Layers I and IV & High & High \\
\hline \multicolumn{3}{|l|}{ Trigeminal nerve } \\
\hline Spinal tract nucleus & High & Moderate \\
\hline \multicolumn{3}{|l|}{ Spinal cord } \\
\hline Substantia gelatinosa & High & High \\
\hline Corpus callosum & Moderate & Low \\
\hline Midbrain & Moderate & Low \\
\hline Medulla & Moderate & Low \\
\hline Pons & Moderate & Low \\
\hline
\end{tabular}

${ }^{a}$ Rat brain. 
are localized in areas lacking nerve endings containing the transmitter. Despite general similarities, there are numerous differences between the localizations of putative neurotransmitlers and their receptors as has been demonstrated for enkephalin (Simantov et al., 1977), thyrotropin-releasing hormone (Burt and Snyder, 1975), neurotensin (Young and Kuhar, 1979a), and norepinephrine (Alexander et al., 1975). One explanation for these discrepancies is that this binding technique labels receptors undergoing axonal transport (Young et al., 1980) as well as synaptically functional receptors.

The use of the mouse for most 5 -nucleotidase localizations and the rat for adenosine receptor autoradiography also may account in part for discrepancies, as species differences exist in the regional localization of adenosine receptors (Murphy and Snyder, 1982). Indeed, in the rat hippocampus, $5^{\prime}$-nucleotidase is highly concentrated in regio superior with a much more restricted distribution in regio inferior, while the reverse occurs in the mouse (Scott, 1967; Schubert ct al., 1979).

\section{References}

Alexander, R. W., J. N. Davis, and R. J. Lefkowitz (1975) Direct identification and characterization of $\beta$-adrenergic receptors in rat brain. Nature 258: 437-440.

Bernstein, H. -G., J. Weiss, and H. Luppa (1978) Cytochemical investigations on the localization of $5^{\prime}$-nucleotidase in the rat hippocampus with special reference to synaptic regions. Histochemistry 55: 261-267.

Bruns, R. F., J. W. Daly, and S. H. Snyder (1980) Adenosine receptors in brain membranes: Binding of $N^{6}$-cyclohexyl $\left[{ }^{3} \mathrm{H}\right]$ adenosine and 1,3'-diethyl-8-[ $\left.{ }^{3} \mathrm{H}\right]$ phenylxanthine. Proc. Natl. Acad. Sci. U. S. A. 77: 5547-5551.

Burt, D. R., and S. H. Snyder (1975) Thyrotropin releasing hormone (TRH): Apparent receptor binding in rat brain membranes. Brain Res. 93: 309-328.

Cammer, W., S. R. Sirota, T. R. Zimmerman, Jr., and W. T. Norton (1980) 5 '-Nucleotidase in rat brain myelin. J. Neurochem. 35: 367-373.

Daly, J. W., R. F. Bruns, and S. H. Snyder (1981) Adenosine receptors in the central nervous system: Relationship to the central actions of methylxanthines. Life Sci. 28: 2083-2097.

Gavish, M., R. R. Goodman, and S. H. Snyder (1982) Solubilized adenosine receptors in the brain regulated by guanine nucleotides. Science 215: 1633-1635.

Groodman, R. R., and S. H. Snyder (1981) The light microscopic in vitro autoradiographic localization of adenosine $\left(A_{1}\right)$ receptors. Soc. Neurosci. Abstr. 7: 613.

Goodman, R. R., M. J. Cooper, M. Gavish, and S. H. Snyder (1982) Guanine nucleotide and cation regulation of the binding of $\left[{ }^{3} \mathrm{H}\right]$ cyclohexyladenosine and $\left[{ }^{3} \mathbf{H}\right]$ diethylphenylxanthine to adenosine $A_{1}$ receptors in brain membranes. Mol. Pharmacol. 21: 329-335.

Hollins, C., and T. W. Stone (1980) Adenosine inhibition of $\gamma$ aminobutyric acid release from slices of rat cerebral cortex. Br. J. Pharmacol. 69: 107-112.

Israel, M., B. Lesbats, R. Manaranche, J. Marsal, P. MastourFrachon, and F. M. Meunier (1977) Related changes in amounts of ACh and ATP in resting and active Torpedo nerve electroplaque synapses. J. Neurochem. 28: 1259-1267.

Konig, J. R., and R. A. Klippel (1963) A Stereotaxic Atlas of the Forebrain and Lower Parts of the Brain Stem, Robert E. Krieger Publishing Co., Inc., Huntington, NY.

Lewis, M. E., J. Patel, S. Moon Edley, and P. J. Marangos (1981) Autoradiographic visualization of rat brain adenosine receptors using $N^{6}$-cyclohexyl[ $\left.{ }^{3} \mathrm{H}\right]$ adenosine. Eur. J. Pharmacol. 73: 109-110.
Londos, C., and J. Wolff (1977) Two distinct adenosine-sensitive sites on adenylate cyclase. Proc. Natl. Acad. Sci. U. S. A. 74: 5482-5486.

Marangos, P. J., S. M. Paul, A. M. Parma, F. K. Goodwin, P. Spin, and P. Skolnick (1979) Purinergic inhibition of diazepam binding to rat brain (in vitro). Life Sci. 24: 851-858.

Marani, E. (1977) The subcellular distribution of $5^{\prime}$-nucleotidase activity in mouse cerebellum. Exp. Neurol. 57: 1042-1048.

Michaelis, M. L., E. K. Michaelis, and S. L. Myers (1979) Adenosine modulation of synaptosomal dopamine release. Life Sci. 24: 2083-2092.

Miyamoto, M. D., and B. M. Breckenridge (1974) A cyclic adenosine monophosphate link in the catecholamine enhancement of transmitter release at the neuromuscular junction. J. Gen. Physiol. 63: 609-624.

Murphy, K. M. M., and S. H. Snyder (1981) Adenosine receptors in rat testes: Labeling with $\left[{ }^{3} \mathrm{H}\right]$ cyclohexyladenosine. Life Sci. 28: 917-920.

Murphy, K. M. M., and S. H. Snyder (1982) Heterogeneity of adenosine $A_{1}$ receptor binding in brain tissue. Mol. Pharmacol. 22: 250-257.

Palkovitz, M., and D. M. Jacobowitz (1974) Topographic atlas of catecholamine and acetylcholinesterase-containing neurons in the rat brain. J. Comp. Neurol. 157: 29-42.

Phillis, J. W., and P. H. Wu (1981) The role of adenosine and its nucleotides in central synaptic transmission. Prog. Neurobiol. 16: 187-239.

Phillis, J. W., J. P. Edstrom, G. K. Kostopoulos, and J. R. Kirkpatrick (1979) Effects of adenosine and adenine nucleotides on synaptic transmission in the cerebral cortex. Can. J. Physiol. Pharmacol. 57: 1289-1312.

Phillis, J. W., A. S. Bender, and P. H. Wu (1980) Benzodiazepines inhibit adenosine uptake into rat brain synaptosomes. Brain Res. 195: 494-498.

Pilcher, C. W. T., and D. G. Jones (1970) The distribution of $5^{\prime}-$ nucleotidase in subcellular fractions of mouse cerebellum. Brain Res. 24: 143-147.

Schubert, P., W. Komp, and G. W. Kreutzberg (1979) Correlation of 5 -nucleotidase activity and selective transneuronal transfer of adenosine in the hippocampus. Brain Res. 168: 419-424.

Schwabe, U., and T. Trost (1980) Characterization of adenosine receptors in rat brain by $(-)\left[{ }^{3} \mathrm{H}\right] N^{6}$-phenylisopropyladenosine. Naunyn Schmiedeberg's Arch. Pharmacol. 313: 179-187.

Scott, T. G. (1964) A unique pattern of localization within the cerebellum of the mouse. J. Comp. Neurol. 122: 1-8.

Scott, T. G. (1965) The specificity of $5^{\prime}$-nucleotidase in the brain of the mouse. J. Histochem. Cytochem. 13: 657-667.

Scott, T. G. (1967) The distribution of $5^{\prime}$-nucleotidase in the brain of the mouse. J. Comp. Neurol. 129: 97-113.

Simantov, R., M. J. Kuhar, G. R. Uhl, and S. H. Snyder (1977) Opioid peptide enkephalins: Immunohistochemical mapping in rat central nervous system. Proc. Natl. Acad. Sci. U. S. A. 74: $2167-2171$.

Smellie, F. W., J. W. Daly, T. V. Dunwiddie, and B. J. Hoffer (1979) The dextro and levorotatory isomers of $N$-phenylisopropyladenosine: Stereospecific effects on cyclic AMP-formation and evoked synaptic responses in brain slices. Life Sci. 25: 1739-1748.

Snyder, S. H., J. J. Katims, Z. Annau, R. F. Bruns, and J. W. Daly (1981) Adenosine receptors and behavioral actions of methylxanthines. Proc. Natl. Acad. Sci. U. S. A. 78: 3260-3264.

Trost, T., and U. Schwabe (1981) Adenosine receptors in fat cells: Identification by $\left.(-) N^{6} \cdot{ }^{3} \mathrm{II}\right]$ phenylisopropyladenosine binding. Mol. Pharmacol. 19: 228-235.

Unnerstall, J. R., M. J. Kuhar, D. L. Niehoff, and J. M. Palacios (1981) Benzodiazepine receptors are coupled to a subpopulation of $\gamma$-aminobutyric acid (GABA) receptors: Evidence 
from a quantitative autoradiographic study. J. Pharmacol. Exp. Ther. 218: 797-804.

van Calker, D., M. Muller, and B. Hamprecht (1979) Adenosine regulates via two different types of receptors the accumulation of cyclic AMP in cultured brain cells. J. Neurochem. 33: 999-1005.

Williams, M., and E. A. Risley (1980) Biochemical characterization of putative purinergic receptors by using 2 -chloro $\left[{ }^{3} \mathrm{H}\right]$ adenosine, a stable analog of adenosine. Proc. Natl. Acad. Sci. U. S. A. 77: 6892-6896.

Young, A. B., M. L. Oster-Granite, R. M. Herndon, and S. H. Snyder (1974) Glutamic acid: Selective depletion by viral induced granule cell loss in hamster cerebellum. Brain Res. 73: 1-13.
Young, W. S., III, and M. J. Kuhar (1979a) Neurotensin receptors: Autoradiographic localization in rat CNS. Eur. J. Pharmacol. 59: 161-163.

Young, W. S., III, and M. J. Kuhar (1979b) A new method for receptor autoradiography: $\left[{ }^{3} \mathrm{H}\right]$ Opioid receptors in rat brain. Brain Res. 179: 255-270.

Young, W. S., III, and M. J. Kuhar (1980) Radiohistochemical localization of benzodiazepine receptors in rat brain. J. Pharmacol. Exp. Ther. 212: 337-346.

Young, W. S., III, J. K. Wamsley, M. A. Zarbin, and M. J. Kuhar (1980) Opioid receptors undergo axonal flow. Science $210: 76-78$. 